\title{
Possibilities of Photodynamic Therapy in the Treatment of Multiple Cylindroma of the Scalp: The Clinical Case Study
}

\author{
Nasrulla Shanazarov $^{1 \star}$ (D), Valery Benberin ${ }^{1}$ (D), Sergey Zinchenko ${ }^{2}$ (D), Fatima Nalgieva ${ }^{3}$ (D), Niyaz Muratov ${ }^{2}$ (D), \\ Bakitzhan Isahanova ${ }^{1}$ (D) , Tokhirzhan Tashpulatov $^{1}$ (D)
}

\author{
${ }^{1}$ Medical Centre Hospital of President's Affairs Administration of the Republic of Kazakhstan, Nur-Sultan, KAZAKHSTAN \\ ${ }^{2}$ Kazan Federal University, Kazan, RUSSIA \\ ${ }^{3}$ Multidisciplinary Medical Center, Nur-Sultan, KAZAKHSTAN \\ *Corresponding Author: nasrulla@inbox.ru
}

Citation: Shanazarov N, Benberin V, Zinchenko S, Nalgieva F, Muratov N, Isahanova B, Tashpulatov T. Possibilities of Photodynamic Therapy in the Treatment of Multiple Cylindroma of the Scalp: The Clinical Case Study. Electron J Gen Med. 2022;19(2):em359. https://doi.org/10.29333/ejgm/11580

\section{ARTICLE INFO}

Received: 28 Oct. 2021

Accepted: 17 Jan. 2022

\begin{abstract}
This article presents a clinical observation of successful treatment of a patient with multiple cylindroma of the scalp and trunk using photodynamic therapy (PDT) after radiotherapy. The first masses were found in 2008, at the same time they were surgically removed. There has been a progression of the process since 2019 - multiple masses on the scalp and trunk. There was another visit to doctors. After verification of diagnosis radiation therapy was received. However, soon after the treatment, the appearance of new and growth of existing foci has been noted. A multistage PDT with good clinical and cosmetic effect was carried out at Medical Centre Hospital of President's Affairs Administration of the Republic of Kazakhstan.
\end{abstract}

Keywords: cylindroma, radiation therapy, photodynamic therapy

\section{INTRODUCTION}

Cylindroma (Brook-Spiegler syndrome, turban tumour) is malignant tumour of the dermal appendages, a group of neoplasms that form from the cells of the sebaceous-hair and sweat glands of the skin [1-5]. Cylindroma most commonly affects the scalp. They occur as solitary lesions [6]. Cylindroma can also occur on the trunk and extremities in less than $10 \%$ of cases [7-8]. This neoplasm is usually asymptomatic, but some patients may experience pain [9-11]. Cases with multiple lesions tend to be hereditary [12-15] and clinically present as multiple, smooth, dense, pink to red nodules of various sizes [16]. In such cases, the tumours can grow for a long time. However, malignant transformation of a multiple or solitary cutaneous cylindroma is quite rare [17].

The histogenesis of skin cylindroma remains the subject of vigorous and controversial debate [18-21]. However, a previous immunodetection study showed that cylindroma probably originated from an epithelial hair follicle [22]. A recent immunohistochemical study with CD200 and other stem cell markers also showed that the hair follicle may also be the source of the cylindroma [23]. Although Brook-Spiegler syndrome (BSS), familial cylindromatosis (FC) and multiple familial trichoepic lyoma (MFT) were originally described as separate nosological diseases, these pathologies show overlapping phenotypic manifestations. At the same time, different manifestations of each disease have been reported in the same family. Thus, these three disorders are considered to represent the phenotypic spectrum of a single disease.
The sex ratio, according to different authors, ranges from 1:1 (female predominance) to $3: 2$ and 9:1. In $80 \%$ of cases they are patients over the age of 40 .

The main treatment is surgical removal and high-dose radiation [24-27]. At the same time, dermal cylindroma has a high recurrence rate due to the technical difficulties of surgical and/or radiation treatment. In addition to the radicalism of tumour removal, it is known that the indicators of efficacy of treatment are the achievement of functional and cosmetic results and the reduction of the complication and recurrence index [28]. Photodynamic therapy (PDT) is considered to be the most relevant to the above requirements.

PDT is a two-component treatment. The photosensitizer (PS), which is the first component, accumulates and is retained in tumour tissues longer than in healthy tissues. The second component is light (laser) exposure. By locally irradiating the tumour with light of a certain wavelength corresponding to the absorption peak of the photosensitizer, a photochemical reaction starts in the tumour, producing singlet oxygen and oxygen radicals, which have a toxic effect on the tumour cells. Hence, the tumor is resorbed and gradually being replaced by connective tissue [29]. PDT for skin cancer and its appendages will be used in the next cases: the presence of a tumor occurs in places that are" inconvenient" for the traditional method of treatment (face, head, per auricular area), a high risk of complications during therapy in elderly and somatically burdened patients, and the refusal of other methods of treatment, as well as in the form of palliative care [30-33]. 

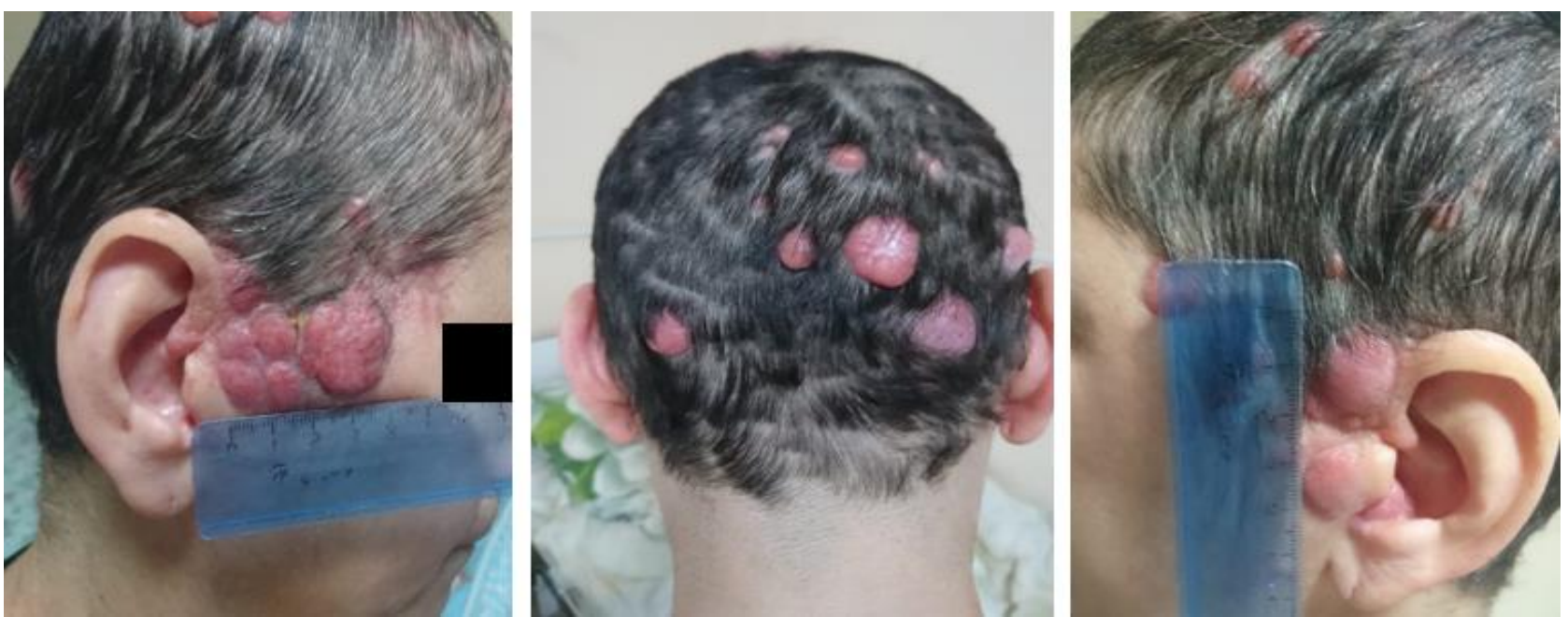

Figure 1. Photo before radiotherapy

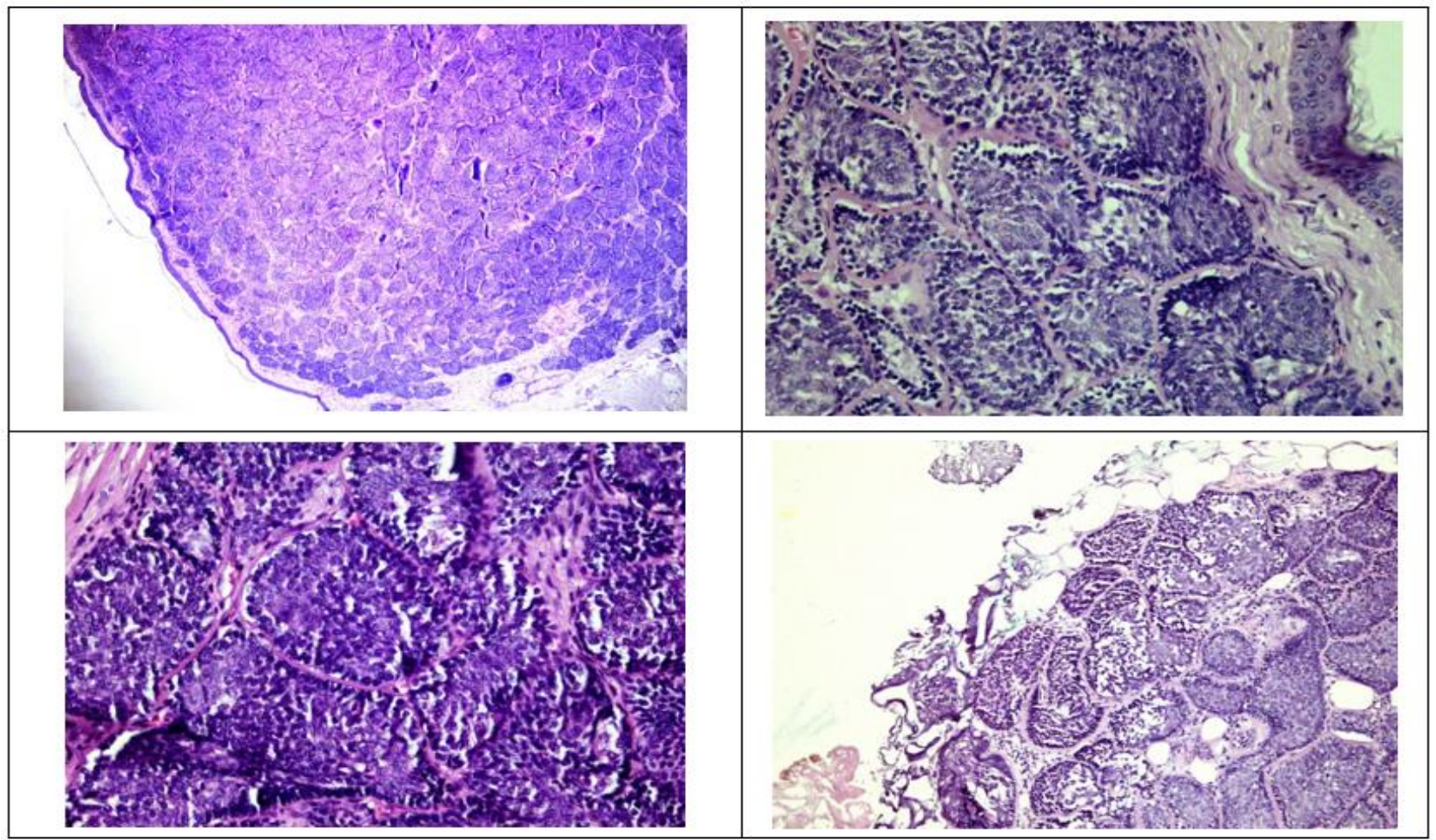

Figure 2. Histological picture before radiotherapy

\section{MATERIALS AND METHODS}

Patient R. is a 44-year-old Asian woman. She first discovered a single, pale pink, dense-elastic mass on her scalp in 2008. She had no genetic history - no family history of similar masses. These masses had been surgically removed by a surgeon on referral. She has not had any further growths for over 10 years. In 2019, the tumour recurred - multiple masses appeared on the scalp, occipital region, anterior chest wall (Figure 1). A biopsy was performed and the histological conclusion was that the skin cylindroma was malignant (Figure 2). A palliative course of conformal radiation therapy with intensity modulation (fluence) within the beam during irradiation (RapidArc), image-guided radiotherapy (IGRT) was performed in the oncological clinic on the scalp tumours with SFD $3 \mathrm{Gr}$, TFD $51 \mathrm{Gr}$. The therapy resulted in reduction of masses up to $50 \%$, complete remission was not achieved. However, after 3 months, the process has progressed with continued growth of existing masses and the appearance of new lesions. She has been recommended photodynamic therapy (PDT).

At the time of examination, multiple skin tumour-like masses of predominantly circular shape, ranging in size from 0.3 to $2.0 \mathrm{~cm}$ by $0.1-0.3 \mathrm{~cm}$ protruding above skin level, light pink color, softly elastic consistency was identified on the scalp. Some of the masses were confluent (Figure 3). Similar masses were detected on the skin of the anterior abdominal wall, skin of the back with sizes ranging from $2 \times 4$ to $3 \times 6 \mathrm{~cm}$ (total number of masses on the scalp and torso-64). In view of the continued growth after radiation therapy, a repeat biopsy was performed. Histological report: eccrine skin cylindroma with signs of grade III curative pathomorphosis (Figure 4). 

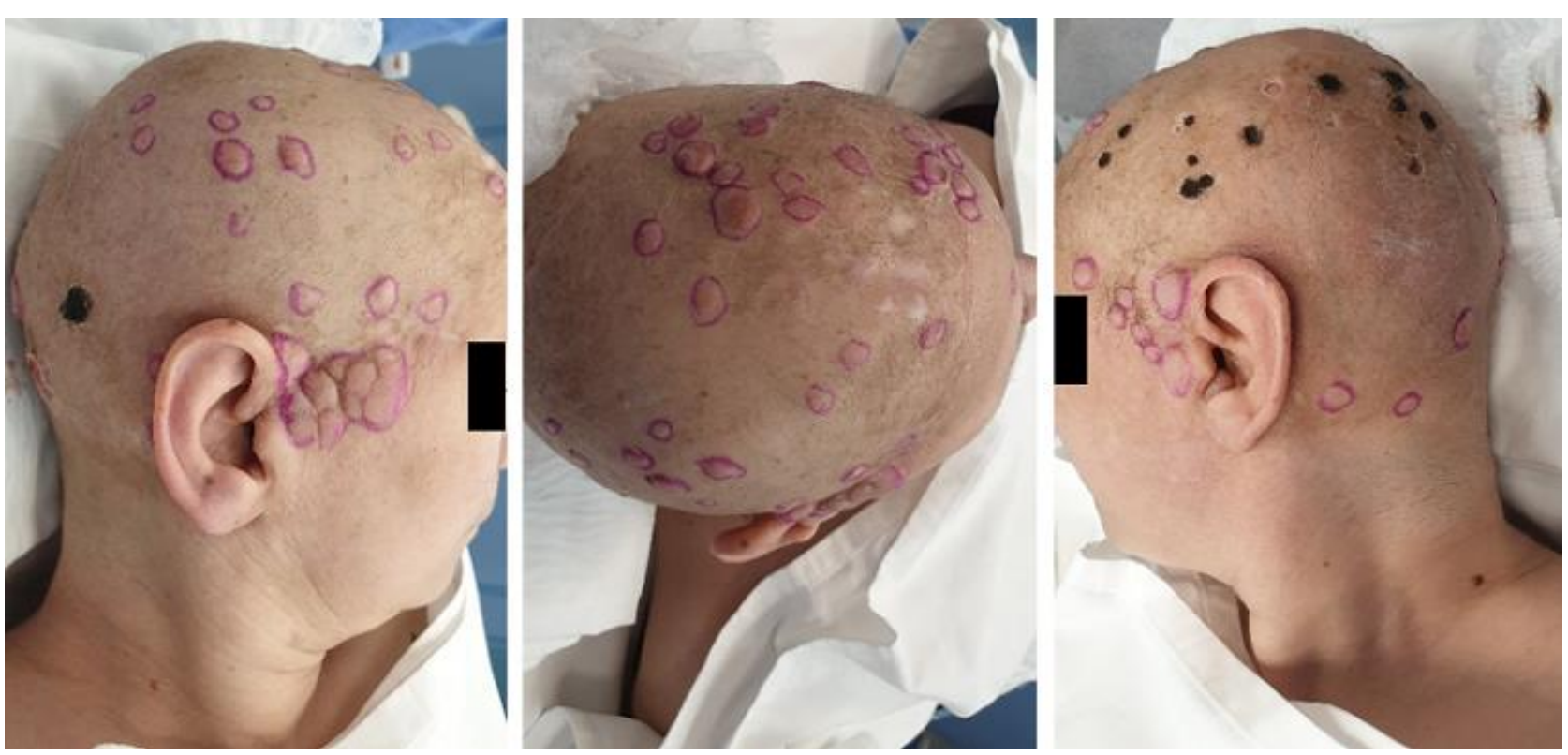

Figure 3. Photo before PDT

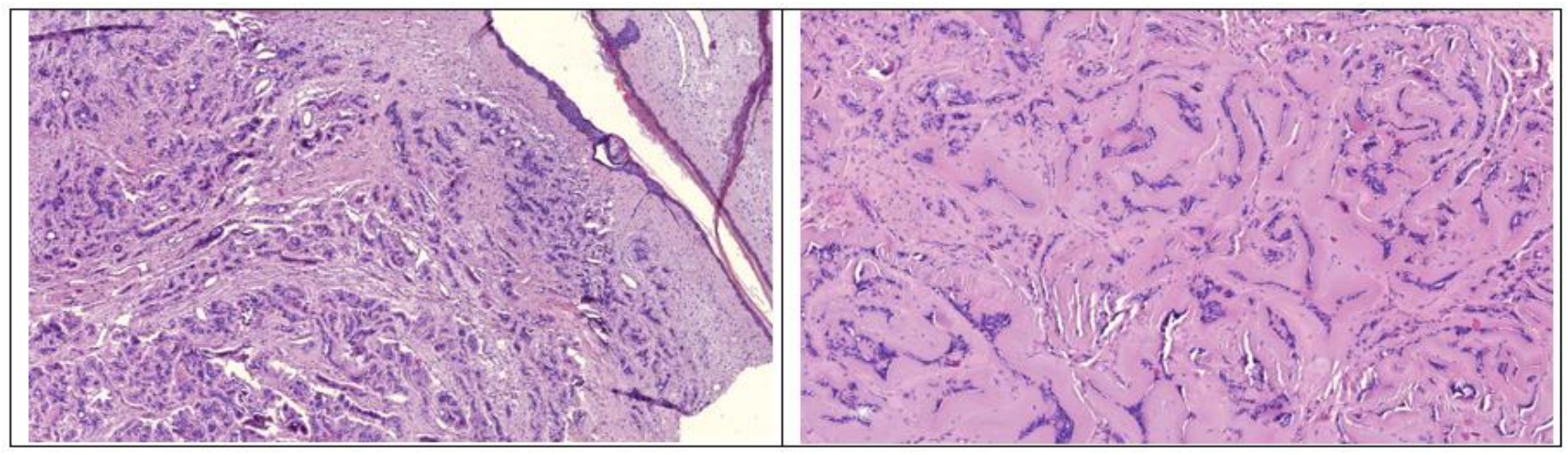

Figure 4. Histological picture after radiotherapy
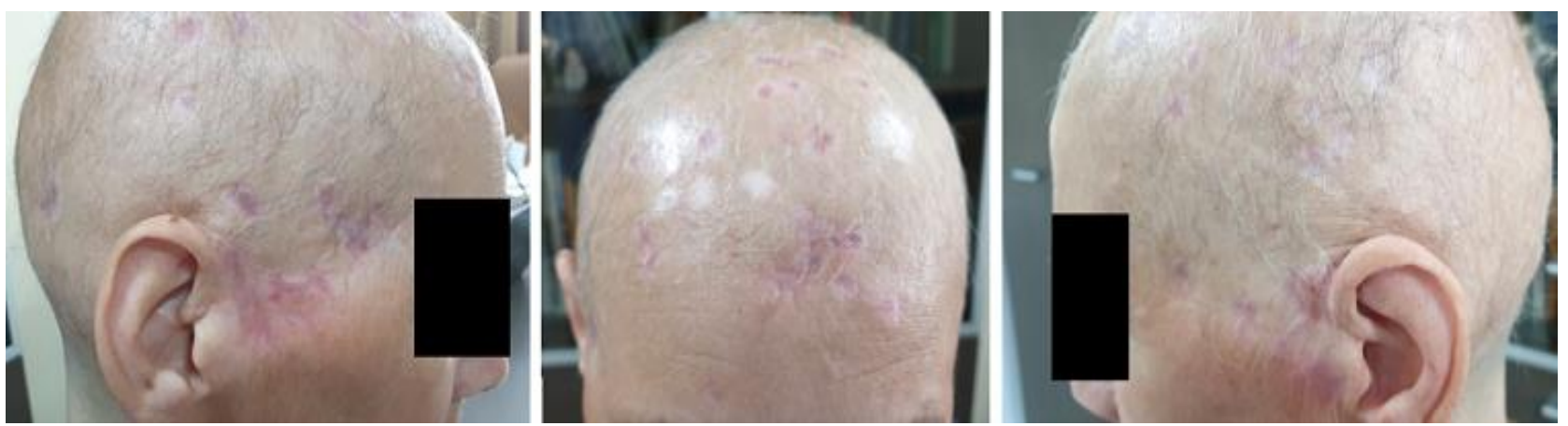

Figure 5. Photo 2 months after PDT

Multistage PDT was performed. The first stage involved the laser treatment of 25 small lesions-up to $1 \mathrm{~cm}$ in size-under local anesthesia. After 3 weeks, the remaining 39 were treated under general anesthesia.

As a photosensitizer, Photolon was administered to the patient at a dose of $2 \mathrm{mg} / \mathrm{kg}$ weight 2 hours before the PDT session. Photolone is a second-generation photosensitizer and is a chlorine E6 derivative with an absorption peak in the longwavelength region of the spectrum equal to $662 \mathrm{~nm}$. This wavelength in the absorption spectrum allows light, excitatory photo activity of the drug, to penetrate deep into tissues by 0.5 $1 \mathrm{~cm}$. Laser treatment was performed with Lahta-Milon laser light guide, 3W output power, wavelength $662 \mathrm{~nm}$. Each lesion was treated for 1 to 3 minutes. Total laser exposure time was 135 minutes.

Thereafter, the patient was examined regularly, the growth of old and new masses was not observed. The necrotic lesions in the area of the masses were gradually replaced by scar tissue. Complete scarring was seen after 2 months (Figure 5). Written informed consent was obtained from the patient for publication of this case and any accompanying images. This case was conducted in compliance with the principles of the Declaration of Helsinki. 


\section{CONCLUSIONS}

Cylindroma is a benign tumour of the dermal appendages, a group of neoplasms that form from the cells of the oil and hair apparatus, the sweat glands of the skin, and in some cases, especially in multinodular forms, can become malignant. Cylindroma mostly affects the scalp. Surgical excision is the main method of treatment for a cylindroma. However, this method of treatment is ineffective in the node form. In our case, PDT has been demonstrated to be highly effective, organpreserving and gentle, with no local or general complications, and is well tolerated. It is also possible to perform the procedure on an outpatient basis.

Author contributions: All authors have sufficiently contributed to the study, and agreed with the results and conclusions.

Funding: No funding source is reported for this study.

Declaration of interest: No conflict of interest is declared by authors.

\section{REFERENCES}

1. Sellheyer K. Spiradenoma and cylindroma originate from the hair follicle bulge and not from the eccrine sweat gand: An immunohistochemical study with CD200 and other stem cell markers. J Cutan Pathol. 2015;42(2):90-101. https://doi.org/10.1111/cup.12406 PMid:25354097

2. Calonje E. Tumours of the skin appendages. In: Burns T, Breathnach S, Cox N, Griffiths C, eds. Rook's textbook of dermatology. Singapore: Wiley-Blackwell; 2010. p. 28-53. https://doi.org/10.1002/9781444317633.ch53 PMid: 20055901

3. Rajan N, Ashworth A. Inherited cylindromas: Lessons from a rare tumour. Lancet Oncol. 2015;16(9):e460-e9. https://doi.org/10.1016/S1470-2045(15)00245-4 PMid: 26370355

4. Saga K. Histochemical and immunohistochemical markers for human eccrine and apocrine sweat glands: An aid for histopathologic differentiation of sweat gland tumors. J Investig Dermatol Symp Proc. 2001;6(1):49-53. https://doi.org/10.1046/j.0022-202x.2001.00005.x PMid: 11764285

5. Blake PW, Toro JR. Update of cylindromatosis gene (CYLD) mutations in Brooke-Spiegler syndrome: Novel insights into the role of deubiquitination in cell signaling. Hum Mutat. 2009;30(7):1025-36. https://doi.org/10.1002/humu. 21024 PMid:19462465 PMCid:PMC3243308

6. Bowen S, Gill M, Lee DA, et al. Mutations in the CYLD gene in Brooke-Spiegler syndrome, familial cylindromatosis, and multiple familial trichoepithelioma: Lack of genotypephenotype correlation. J Invest Dermatol. 2005;124(5):91920. https://doi.org/10.1111/j.0022-202X.2005.23688.x PMid: 15854031

7. Tauriello DVF, Haegebarth A, Kuper I, et al. Loss of the tumor suppressor CYLD enhances Wnt/beta-catenin signaling through K63-linked ubiquitination of Dvl. Mol Cell. 2010;37(5):607-19. https://doi.org/10.1016/j.molcel. 2010.01.035 PMid:20227366

8. Sun S-C. CYLD: A tumor suppressor deubiquitinase regulating NF-kappaB activation and diverse biological processes. Cell Death Differ. 2010;17(1):25-34. https://doi.org/10.1038/cdd.2009.43 PMid:19373246 PMCid:PMC5848464
9. Durani BK, Kurzen $\mathrm{H}$, Jaeckel $\mathrm{A}$, Kuner $\mathrm{N}$, Naeher $\mathrm{H}$, Hartschuh W. Malignant transformation of multiple dermal cylindromas. $\mathrm{Br} \mathrm{J}$ Dermatol. 2001;145(4):653-6. https://doi.org/10.1046/j.1365-2133.2001.04460.x PMid: 11703297

10. Weedon D. Tumors of cutaneous appendages. In: Weedon D, ed. Weedon's skin pathology. China: Elsevier; 2010:7856. https://doi.org/10.1016/b978-0-7020-3485-5.00034-6

11. Bignell GR, Warren W, Seal S, et al. Identification of the familial cylindromatosis tumour-suppressor gene. Nat Genet. 2000;25(2):160-5. https://doi.org/10.1038/76006 PMid:10835629

12. Massoumi R. CYLD: A deubiquitination enzyme with multiple roles in cancer. Future Oncol. 2011;7(2):285-97. https://doi.org/10.2217/fon.10.187 PMid:21345146

13. Canedo T, de Almeida MP, Cuzzi T, Ramos-e-Silva M. Immunophenotypic aspects of cylindroma and nodular hidradenoma. J Eur Acad Dermatol Venereol. 2010;24(2):178-85. https://doi.org/10.1111/j.1468-3083. 2009.03398.x PMid:19796089

14. Cotton DW, Braye SG. Dermal cylindromas originate from the eccrine sweat gland. Br J Dermatol. 1984;111(1):53-61. https://doi.org/10.1111/j.1365-2133.1984.tb04016.x PMid:6331489

15. Missall TA, Burkemper NM, Jensen SL, Hurley MY. Immunohistochemical differentiation of four benign eccrine tumors. J Cutan Pathol. 2009;36(2):190-6. https://doi.org/10.1111/j.1600-0560.2008.00991.x PMid: 18564284

16. Penneys NS, Kaiser M. Cylindroma expresses immunohistochemical markers linking it to eccrine coil. J Cutan Pathol. 1993;20(1):40-3. https://doi.org/10.1111/ j.1600-0560.1993.tb01247.x PMid:7682227

17. Hashimoto K, Lever WF. Histogenesis of skin appendage tumors. Arch Dermatol. 1969;100(3):356-69. Error! Hyperlink reference not valid. PMid:4309779

18. Layegh $\mathrm{P}$, Sharifi-Sistani N, Abadian M, Moghiman T. Brooke-Spiegler syndrome. Indian J Dermatol Venereol Leprol. 2008;74:632-4. https://doi.org/10.4103/0378-6323. 45109 PMid:19171990

19. Bilyalov AI, Shanazarov NA, Zinchenko SV. Photodynamic therapy as alternative method of treatment of metastatic ovarian cancer with many recurrence: Case report. CA Cancer J Clin. 2011;61(4):250-81. https://doi.org/10.1007/ s12668-020-00749-7 PMid:21617154 PMCid:PMC3209659

20. Oosterkamp HM, Neering H, Nijman SM, et al. An evaluation of the efficacy of topical application of salicylic acid for the treatment of familial cylindromatosis. $\mathrm{Br} \mathrm{J}$ Dermatol. 2006;155(1):182-5. https://doi.org/10.1111/j.1365-2133. 2006.07224.x PMid:16792771

21. Brass D, Rajan N, Langtry J. Enucleation of cylindromas in Brooke-Spiegler syndrome: A novel surgical technique. Dermatol Surg. 2014;40(12):1438-9. https://doi.org/10. 1097/DSS.0000000000000142 PMid:25361203 PMCid: PMC6082342

22. Massoumi R, Podda M, Fassler R, Paus R. Cylindroma as tumor of hair follicle origin. J Invest Dermatol. 2006;126(5):1182-4. https://doi.org/10.1038/sj.jid.5700218 PMid:16484982

23. Rajan N, Andersson M, Sinclair A, et al. Overexpression of MYB drives proliferation of CYLD-defective cylindroma cells. J Pathol. 2016;239(2):197-205. https://doi.org/10. 1002/path.4717 PMid:26969893 PMCid:PMC4869681 
24. Richard A, Chevalier JM, Verneuil L, et al. CO2 laser treatment of skin cylindromas in Brooke-Spiegler syndrome. Dermatol Surg. 2000;26(9):877-80; discussion 881. https://doi.org/10.1046/j.1524-4725.2000.00034.x PMid:10971563

25. Rajan N, Trainer AH, Burn J, Langtry JA. Familial cylindromatosis and Brooke-Spiegler syndrome: A review of current therapeutic approaches and the surgical challenges posed by two affected families. Dermatol Surg. 2009;35(5):845-52. https://doi.org/10.1111/j.1524-4725. 2009.01142.x PMid:19397670

26. Aguilera CA, de la Varga R, García LO, Jiménez D, Planelles CA, Barrios ML. Heterozygous cylindromatosis gene mutation c.1628_1629delct in a family with Brook-Spiegler syndrome. Indian J Dermatol. 2016;61(5):580. https://doi.org/10.4103/0019-5154.190130 PMid:27688459 PMCid:PMC5029256

27. Dhua S, Sekhar DR. A rare case of eccrine spiradenomatreatment and management. Eur J Plast Surg. 2016;39:1436. https://doi.org/10.1007/s00238-015-1103-4 PMid: 27069311 PMCid:PMC4803810

28. Ankad BS, Beergouder SL, Domble V, Sujana L. A serpentine inside eccrine spiradenoma: A new trichoscopic sign. Int J Trichology. 2015;7(1):38-40. https://doi.org/10.4103/09747753.153460 PMid:25878450 PMCid:PMC4387699
29. Yen TTH, Ramenskaya GV, Oborotova NA. Chlorin derivatives in cancer photodynamic therapy. Russian $\mathrm{J}$ Biotherapy. 2009;4:99-101.

30. Rajan N, Langtry JA, Ashworth A, Roberts C. Familial cylindromatosis and Brooke-Spiegler syndrome: A review of current therapeutic approaches and the surgical challenges posed by two affected families. Dermatol Surg. 2009;35(5):845-52. https://doi.org/10.1111/j.1524-4725. 2009.01142.x PMid:19397670

31. Jordão C, de Magalhães TC, Cuzzi T, Ramos-e-Silva M. Cylindroma: An update. Int J Dermatol. 2015;54(3):275-8. https://doi.org/10.1111/ijd.12600 PMid:25515269

32. Lallas A, Apalla Z, Tzellos T, Lefaki I. Dermoscopy of solitary cylindroma. Eur J Dermatol. 2011;21(4):645-6. https://doi.org/10.1684/ejd.2011.1413 PMid:21697054

33. Shanazarov N, Zinchenko S, Zhapparov E, et al. The clinical case of successful application of photodynamic therapy in the skin metastases treatment of breast cancer. BioNanoScience. 2021;11:957-61. https://doi.org/10.1007/ s12668-021-00907-5 